\title{
SYNTHESIS AND RESOLUTION OF SUBSTITUTED PIPECOLIC ACIDS
}

\author{
C. G. Overberger and M. D. Shalati [1] \\ Department of Chemistry and the Macromolecular Research Center, The University of Michigan, \\ Ann Arbor, MI 48109, U.S.A.
}

\begin{abstract}
A new general method for the preparation of 2-alkyl-pipecolic acids has been developed. The syntheses of 2-methyl-, 2-benzyl- and cis-6-methylpipecolic acids are described. (-)S- and $(+)$ R-2-methylpipecolic acids were resolved by fractional crystallization of the quinine salt of their $N$-carbobenzoxy derivative. Isolation of $(-) \mathrm{S}$-cis-6-methylpipecolic acid required the use of 4-phenylbenzyloxycarbonyl as protecting group to achieve selective crystallization of the quinine salt. The absolute configurations of these compounds were determined by circular dichroism.
\end{abstract}

\section{INTRODUCTION}

For some time we have been involved in the study of substituent effects on the polymerization of cyclic imino acids and of the conformational behaviour of the corresponding polypeptides [2-6]. This paper deals with the syntheses of 2-methyl-, 2-benzyl- and cis-6-methylpipecolic acids (2MPA, 2BPA and c6MPA, respectively) and with the resolution of 2-methyl- and cis-6-methylpipecolic acids. The following papers in this series will describe the dimerization of $N$-carboxyanhydrides of 2MPA and c6MPA [7] and report on the conformations of some diketopiperazines derived from 2MPA $c 6$ MPA [7] and report on the conformations of some diketopiperazines derived from 2MPA and $t 6 \mathrm{MPA}$ in solution and in the solid state [8].

\section{EXPERIMENTAL}

All melting points were determined in open capillary tubes on a Thomas Hoover Capillary Melting Point Apparatus and were uncorrected. Elemental analyses were performed by Spang Laboratories, Inc., Knoxville, Tennessee. Specific rotations at the sodium D line were measured by a Perkin-Elmer 241 MC and Rudolf polarimeter. Circular dichroism spectra were recorded on a JASCO J-40A spectropolarimeter using $0.1-1.0 \mathrm{~mm}$ cells. I.R. spectra were recorded on a Perkin-Elmer Model 257 spectrophotometer NMR spectra were recorded on a Varian T-60 spectrophotometer

\section{Ethyl-1-methyl-2-oxocyclopentanecarboxylate (2b)}

Compound $\mathbf{2 b}$ was prepared according to the method of Claisen as modified by Barco, Benetti and Pollini [14] Vigorous stirring of a mixture of $\mathrm{K}_{2} \mathrm{CO}_{3}(351.6 \mathrm{~g}, 2.54 \mathrm{~mol})$, acetone $(500 \mathrm{ml})$, ethyl 2-oxocyclopentanecarboxylate $(99.4 \mathrm{~g}, 0.636 \mathrm{~mol})$ and iodomethane $(180.5 \mathrm{~g}, 1.27 \mathrm{~mol})$, produced ethyl 1-methyl-2-oxocyclopentanecarboxylate $(106.0 \mathrm{~g}, 0.62 \mathrm{~mol})$ in $97.5 \%$ yield; b.p. $117-118^{\circ} / 20 \mathrm{mmHg}$ (lit. [14] $107^{\circ} / 15 \mathrm{mmHg}$ ).

$\operatorname{NMR}\left(\mathrm{CDCl}_{3}\right) \delta: 1.23(3 \mathrm{H}, \mathrm{t}, \mathrm{J}=7 \mathrm{~Hz}), 4.1\left(2 \mathrm{H}_{\mathrm{x}}, \mathrm{q}, \mathrm{J}\right.$ $=7 \mathrm{~Hz}) ; 1.27(3 \mathrm{H}, \mathrm{S}) ; 1.80-2.40(6 \mathrm{H}, \mathrm{m})$.

I.R. (neat): $2880-2980,1750,1725,1460,1450,1410$, $1380,1320,1275,1240,1190,1150,1070,1030,950,865$ and $815 \mathrm{~cm}^{-1}$.
Methyl 1-methyl-2-oxocyclopentanecarboxylate (2a)

The same procedure used for the preparation of $\mathbf{2 b}$ was employed here. The scale was three times that of the above example; yield $87-97 \%$; b.p.; $96 \% 11 \mathrm{mmHg}$, (lit. [7] $102^{\circ} \mathrm{C} / 13 \mathrm{mmHg}$ )

NMR $\left(\mathrm{CDCl}_{3}\right) \delta$ : Methyl ester, $3.6(3 \mathrm{H}, \mathrm{s})$; methylene group, $1.8-2.5(6 \mathrm{H}, \mathrm{m}) ; \alpha$-methyl, $1.25(3 \mathrm{H}, \mathrm{s})$.

I.R. (neat): $2890-2990,1760,1730,1465,1455,1440$, $1410,1380,1320,1275,1240,1200,1160,1070,985$ and $945 \mathrm{~cm}^{-1}$.

\section{Ethyl 2-methyl-6-oxopipecolate (3b)}

The procedure of Plostnieks [13] was modified in the following manner. In a 21, 3-necked flask equipped with mechanical stirrer, pressure equalizing funnel, thermometer, and gas outlet were placed a dry solution of hydrazoic acid in chloroform $(700 \mathrm{ml} / 0.45 \mathrm{~N}, 0.315 \mathrm{~mol})$ and $2 \mathrm{~b}(34 \mathrm{~g}$, $0.2 \mathrm{~mol})$. The solution was stirred and cooled to $-10^{\circ}$. Conc. sulphuric acid $(70 \mathrm{ml})$ was added dropwise $(2 \mathrm{hr})$, keeping the temperature below $-5^{\circ}$. About 5.51 of $\mathrm{N}_{2}$ were evolved. Stirring was continued at room temperature for one additional hour and the excess of hydrazoic acid evolved was trapped in aqueous $\mathrm{NaOH}$. The chloroform layer was decanted from the $\mathrm{H}_{2} \mathrm{SO}_{4}$ layer which contained most of the product. The $\mathrm{H}_{2} \mathrm{SO}_{4}$ layer was poured over ice $(500 \mathrm{~g})$ with stirring and external cooling, neutralized $\left(\mathrm{Na}_{2} \mathrm{CO}_{3}\right)$, and extracted with methylene chloride. The chloroform layer was combined with the methylene chloride extracts. After drying, filtration and evaporation of the solvents in a rotary evaporator, a yellow oily residue was obtained which solidified upon standing. Crystallization was carried out in 1,2-dimethoxyethane to give $25 \mathrm{~g} \mathrm{(67 \%} \mathrm{yield)}$ of colorless crystals, m.p. 64-65

Analysis. Calculated for $\mathrm{C}_{9} \mathrm{H}_{15} \mathrm{NO}_{3}: \mathrm{C}, 58.35 ; \mathrm{H}, 8.11 ; \mathrm{N}$, 7.57. Found: C, $58.38 ; \mathrm{H}, 8.05 ; \mathrm{N}, 7.65$.

NMR $\left(\mathrm{CDCl}_{3}\right) \delta$ : Amide, $7.2(1 \mathrm{H}, \mathrm{s})$; ethyl ester $\left(\mathrm{A}_{3} \mathrm{X}_{2}\right.$ pattern), $4.15\left(2 \mathrm{H}_{\mathrm{X}}, \mathrm{q}, \mathrm{J}_{\mathrm{AX}}=7\right), 1.3\left(3 \mathrm{H}_{\mathrm{A}}, \mathrm{t}, \mathrm{J}_{\mathrm{AX}}=7\right)$; methylene group, 1.6-2.5 (6H, m); $\alpha$-methyl, $1.45(3 \mathrm{H}, \mathrm{s})$.

I.R. $(\mathrm{KBr}): 3200,3080,2980-2900,1740,1670,1460$, $1410,1340,1300,1245,1180,1125,1030$ and $830 \mathrm{~cm}^{-1}$

\section{Methyl 2-methyl-6-oxopipecolate (3a)}

The above procedure was used with the following modifications. Hydrazoic acid in chloroform $(2000 \mathrm{ml}$ $0.65 \mathrm{~N}, 1.3 \mathrm{~mol}), 2 \mathrm{a}(156 \mathrm{~g}, 1.0 \mathrm{~mol})$, and $\mathrm{H}_{2} \mathrm{SO}_{4}(200 \mathrm{ml})$ were treated as in the above example $(4 \mathrm{hr})$. During the work-up procedure, the solid sodium sulphate, resulting 
from neutralizing the $\mathrm{H}_{2} \mathrm{SO}_{4}$, was filtered before extraction. The yellow solid product was triturated with diethyl ether to remove impurities and colour. Crystallization from 1,2-dimethoxyethane raised the melting point from $98-99$ to 98.5-99.5 and gave pure colourless crystals $(128.0 \mathrm{~g}$, yield $75 \%$.

Analysis. Calculated for $\mathrm{C}_{8} \mathrm{H}_{13} \mathrm{NO}_{3}: \mathrm{C}, 56.13 ; \mathrm{H}, 7.65 ; \mathrm{N}$ 8.18. Found: $\mathrm{C}, 56.20 ; \mathrm{H}, 7.56 ; \mathrm{N}, 8.27$

NMR $\left(\mathrm{CDCl}_{3}\right) \delta$ : Amide, $7.60(1 \mathrm{H}, \mathrm{s})$; methyl ester, 3.75 $(3 \mathrm{H}, \mathrm{s})$; methylene group, $1.6-2.5(6 \mathrm{H}, \mathrm{m}) ; \alpha$-methyl, 1.45 $(3 \mathrm{H}, \mathrm{s})$.

I.R. (KBr): 3340, 3220, 2890-2990, 1740, 1680, 1450, $1380,1350,1250,1190,1125,1075,1040$ and $770 \mathrm{~cm}^{-1}$.

\section{Ethyl 2-methylpipecolate (6b)}

The procedure of Borch [15] for the reduction of secondary amides was used. Triethyloxonium tetrafluoroborate [16] $(6.64 \mathrm{~g}, 35 \mathrm{mmol}), 3 \mathrm{~b}(6.0 \mathrm{~g}, 32.4 \mathrm{mmol})$, methylene chloride $(25 \mathrm{ml})$, absolute ethanol $(30 \mathrm{ml})$ and sodium borohydride $(3.0 \mathrm{~g}, 79 \mathrm{mmol})$ were used to give ethyl 2 -methylpipecolate $(3.75 \mathrm{~g}, 21.9 \mathrm{mmol})$ in $67.6 \%$ yield; b.p. $78^{\circ}$ $11 \mathrm{mmHg}\left(n_{\mathrm{D}}^{21}, 1.4497\right)$.

Analysis. Calculated for $\mathrm{C}_{9} \mathrm{H}_{17} \mathrm{NO}_{2}: \mathrm{C}, 63.12 ; \mathrm{H}, 10.00$; N, 8.17. Found: C, 62.98; H, 9.92; N, 7.92.

NMR (neat) $\delta$ : Ethyl ester $\left(\mathrm{A}_{3} \mathrm{X}_{2}\right.$ pattern), 4.10 $\left(2 \mathrm{H}_{\mathrm{x}}, \mathrm{q}, \mathrm{J}_{\mathrm{AX}}=7 \mathrm{~Hz}\right), 1.20\left(3 \mathrm{H}_{\mathrm{A}}, \mathrm{t}, \mathrm{J}_{\mathrm{AX}}=7 \mathrm{~Hz}\right)$; methylene group, $\left(\mathrm{CH}_{2}\right) 2.65(2 \mathrm{H}, \mathrm{m}) ;\left(\mathrm{CH}_{2}\right)_{\beta} 2.20(\mathrm{lH}, \mathrm{m}),\left(\mathrm{CH}_{2}\right)_{\beta, \delta}$ $1.30-1.55(5 \mathrm{H}, \mathrm{m})$; amine $1.40(1 \mathrm{H}, \mathrm{s}) ; \alpha-\mathrm{CH}_{3}, 1.15(3 \mathrm{H}, \mathrm{s})$.

I.R. (neat): $3330,2950,2860,1730,1475,1450,1375$, $1295,1240,1130-1190,1105,1055,1030$ and $700 \mathrm{~cm}^{-1}$.

\section{Methyl 2-methylpipecolate (6a)}

The procedure of Borch [15] was modified slightly for large-scale synthesis: (1) The reduction of the imino ether salt was carried out at $0^{\circ}$ for $6 \mathrm{hr}$, and at $25^{\circ}$ for $12 \mathrm{hr}$; (2) the work-up procedure was to filter the solid material, evaporate the ethanol and then to treat with water and extract the product with methylene chloride. Triethyloxonium tetrafluoroborate [16] $(102.5 \mathrm{~g}, 0.54 \mathrm{~mol}), 3 \mathrm{a}(85.5 \mathrm{~g}$, $0.5 \mathrm{~mol})$, methylene chloride $(400 \mathrm{ml})$, absolute ethanol $(600 \mathrm{ml})$ and sodium borohydride $(46.3,1.2 \mathrm{~mol})$ were used to obtain methyl 2-methylpipecolate $(57.0 \mathrm{~g})$ in $73 \%$ yield after vacuum distillation; b.p. $67 \% 8 \mathrm{mmHg}$.

Analysis. Calculated for $\mathrm{C}_{8} \mathrm{H}_{15} \mathrm{NO}_{2}: \mathrm{C}, 61.10 ; \mathrm{H}, 9.62 ; \mathrm{N}$, 8.91. Found: C, 61.15; H, 9.61; N, 8.85 .

NMR (neat) $\delta$ : Methyl ester, $3.65(3 \mathrm{H}, \mathrm{s})$; methylene group, $\left(\mathrm{CH}_{2}\right)_{\mathrm{K}}: 2.70(2 \mathrm{H}, \mathrm{m}),\left(\mathrm{CH}_{2}\right)_{\beta}: 2.10(1 \mathrm{H}, \mathrm{m})$, $\left(\mathrm{CH}_{2}\right)_{\beta, ., \delta}:(5 \mathrm{H}, \mathrm{m}) 1.3-1.55(5 \mathrm{H}, \mathrm{m}), \alpha-\mathrm{CH}_{3} 1.15(3 \mathrm{H}, \mathrm{s})$. I.R. (neat): $3340,2870,2950,1735,1450,1370,1300$, $1240,1100-1200,1050,1000,990,930$ and $750 \mathrm{~cm}^{-1}$.

Methyl 2-methyl-6-ethoxy-2,3,4,5-tetrahydropicolinate (5a)

The free imino ether was obtained by washing its fluoroborate salt in methylene chloride with ice-cold sodium carbonate solution. An analytical sample was prepared and distilled under vacuum; b.p. $125^{\circ} / 20 \mathrm{mmHg}$

Analysis. Calculated for $\mathrm{C}_{10} \mathrm{H}_{17} \mathrm{NO}_{3}: \mathrm{C}, 60.28 ; \mathrm{H}, 8.60 ; \mathrm{N}$, 7.03. Found: $\mathrm{C}, 60.23, \mathrm{H}, 8.60 ; \mathrm{N}, 6.99$.

NMR $\left(\mathrm{CDCl}_{3}\right)$ : Ethyl ether $\left(\mathrm{A}_{3} \mathrm{X}_{2}\right.$ pattern $)$, 4.1 $\left(2 \mathrm{H}_{\mathrm{X}}, \mathrm{q}, \mathrm{J}_{\mathrm{Ax}}=7 \mathrm{~Hz}\right), 1.25\left(3 \mathrm{H}_{\mathrm{A}}, \mathrm{t}, \mathrm{J}_{\mathrm{Ax}}=7 \mathrm{~Hz}\right)$ methyl ester: $3.65(3 \mathrm{H}, \mathrm{s})$, methylene group, $2.3-1.6(6 \mathrm{H}, \mathrm{m}) ; \alpha$-methyl $1.40(3 \mathrm{H}, \mathrm{s})$

I.R. (neat): 2990-2960, 1740, 1675, 1450, 1375, 1350; $1245-1170,1120,1070,1040$ and $770 \mathrm{~cm}^{-1}$.

\section{2-Methylpipecolic acid monohydrate (7)}

Compound $6 \mathrm{a}(200 \mathrm{~g}, 1.27 \mathrm{~mol})$ and water $(2000 \mathrm{ml})$ were refluxed for $1 \mathrm{hr}$ (the ethyl ester needed a longer reaction time, $10 \mathrm{hr}$ ). The reaction mixture was evaporated to dryness and the white residue was crystallized from an ethanol-water mixture (70:30 by vol.). White crystalline needles of $7(193.0 \mathrm{~g})$ were obtained in $94 \%$ yield; m.p. 340 with sublimation.
Analysis. Calculated for $\mathrm{C}_{7} \mathrm{H}_{13} \mathrm{NO}_{2} \cdot \mathrm{H}_{2} \mathrm{O}: \mathrm{C}, 52.16 ; \mathrm{H}$, 9.38; N, 8.69. Found: C, 52.21; H, 9.36; N, 8.72.

Mass spectrum ( $m / e$, abundance): $(144,0.04),(128,1.0)$, $(99,5.4),(98,100),(82,5.9),(70,16.0) ;(69,3.9),(55,9.0)$, $(42,18.0),(41,10.8),(39,5.7),(30,7.2),(28,14.0)$.

$\operatorname{NMR}\left(\mathrm{D}_{2} \mathrm{O}\right) \delta:\left(\mathrm{CH}_{2}\right)_{c}: 3.3-3.6(2 \mathrm{H}, \mathrm{m}),\left(\mathrm{CH}_{2}\right)_{\beta, \gamma}:$ $1.8-2.7(6 \mathrm{H}, \mathrm{m}), \alpha-\mathrm{CH}_{3}, 1.7(3 \mathrm{H}, \mathrm{s})$.

I.R. (K Br): $3400-2400,1590-1620,1515,1450,1395$, $1365,1345,1290,1180,1110,1060,1040,980,870,850$ and $780 \mathrm{~cm}^{-1}$

\section{$N$-carbobenzoxy-2-methylpipecolic acid (17)}

Compound 7 ( $32.2 \mathrm{~g}, 0.20 \mathrm{~mol})$ was dissolved in aqueous $\mathrm{NaOH}(50 \mathrm{ml} 4 \mathrm{~N}, 0.20 \mathrm{~mol})$. The reaction flask was immersed in an ice-bath and the solution was stirred vigorously with a mechanical stirrer. Benzyl chloroformate $(51.1 \mathrm{~g}, 0.30 \mathrm{~mol})$ and aqueous $\mathrm{NaOH}(75 \mathrm{ml} 4 \mathrm{~N}, 0.30 \mathrm{~mol})$ were added alternately in portions over a period of $30 \mathrm{~min}$, maintaining the temperature below $5^{\circ}$. The pasty reaction mixture was stirred and cooled for one additional hour, and the excess benzyl chloroformate was extracted with ether. About 1 litre of water was added to the reaction mixture and brought to boiling. The heterogeneous mixture turned homogeneous after $2.5 \mathrm{hr}$ was subsequently cooled and acidified to $\mathrm{pH} 4$. The resultant milky solution was left at $0^{\circ}$ overnight. Crystalline solid was formed, filtered, dried and recrystallized from chloroform/petroleum ether. Colourless crystals were obtained $(35.7 \mathrm{~g}, 68 \%$ yield $)$; m.p. 119.5-1.20.5

Analysis. Calculated for $\mathrm{C}_{15} \mathrm{H}_{19} \mathrm{NO}_{4}: \mathrm{C}, 64.97 ; \mathrm{H}, 6.91 ; \mathrm{N}$, 5.05. Found: $\mathrm{C}, 64.94 ; \mathrm{H}, 6.85 ; \mathrm{N}, 4.88$.

NMR $\left(\mathrm{d}_{6}\right.$-acetone) $\delta$ : Carboxylic, $9.20(1 \mathrm{H}, \mathrm{s})$, aromatic $7.35(5 \mathrm{H}, \mathrm{s})$, benzylic, $5.10(2 \mathrm{H}, \mathrm{s}),\left(\mathrm{CH}_{2}\right)_{\mathrm{c}}: 4.05-0.65$ $(1 \mathrm{H}, \mathrm{m}), 3.5-2.9(\mathrm{H}, \mathrm{m}),\left(\mathrm{CH}_{2}\right)_{\beta,, \delta} 2.0-1.6(6 \mathrm{H}, \mathrm{m}), \alpha-\mathrm{CH}_{3}$, $1.50(3 \mathrm{H}, \mathrm{s})$.

I.R. (KBr): $3300-3100,2945,2875,1755,1670,1505$, $1480,1425,1360,1280,1240,1210,1185,1145,1090,1035$, $990,915,885,780,750$ and $710 \mathrm{~cm}^{-1}$.

\section{(+)-N-carbobenzoxy-2-methyl-S-pipecolic acid (18)}

Compound $17(28 \mathrm{~g}, 0.10 \mathrm{~mol})$ and quinine $(32.4 \mathrm{~g}$, $0.10 \mathrm{~mol}$ ) were dissolved in hot acetone $(2.5 \mathrm{l})$. The hot solution was filtered and allowed to stand at $5^{\circ}$ overnight. White fluffy crystals were collected and the filtrate saved for the preparation of 21. After four recrystallizations from acetone the $[(+A) \cdot(-B)]$ salt was obtained: $17.0 \mathrm{~g}, 56 \%$ yield, m.p. $164-165^{\circ}[\alpha]_{\mathrm{D}}^{23}=-93.3^{\circ}(\mathrm{MeOH}, c=1.5 \mathrm{~g} / \mathrm{dl})$. The same values were obtained after two additional recrystallizations. This salt was dissolved in $100 \mathrm{ml}$ chloroform and $100 \mathrm{ml}$ aqueous $\mathrm{NH}_{4} \mathrm{OH}(\mathrm{I} \mathrm{N})$ were added dropwise with stirring. The chloroform was evaporated under vacuum, quinine precipitated and removed from the aqueous layer by filtration. The filtrate was brought to $\mathrm{pH} 4$ with $2 \mathrm{~N} \mathrm{HCl}$, the precipitated solid was extracted with chloroform. After drying and removing the solvent, white crystals were obtained and recrystallized from chloroform-hexane to give white needles: $7.6 \mathrm{~g}, 54 \%$ overall yield; m.p. $137.5-139^{\circ},[\alpha]_{\mathrm{D}}^{23}=+25.4^{\circ}(\mathrm{MeOH}, c=5 \mathrm{~g} / \mathrm{dl})$.

NMR and i.r. spectra are the same as for the racemic compound.

Analysis. Calculated for $\mathrm{C}_{15} \mathrm{H}_{19} \mathrm{NO}_{4}: \mathrm{C}, 64.97 ; \mathrm{H}, 6.91 ; \mathrm{N}$ 5.05. Found: C, $64.70 ; \mathrm{H}, 6.73 ; \mathrm{N}, 4.99$.

\section{(-)-N-carbobenzoxy-2-methyl-4-pipecolic acid (21)}

The $[(-\mathrm{A}) \cdot(-\mathrm{B})]$ enriched filtrate obtained from the crystallization of $(+)-N$-carbobenzoxy-2-methyl-S-pipecolic acid quinine salt $[(+\mathbf{A}) \cdot(-\mathbf{B})]$ was evaporated to dryness $(34.0 \mathrm{~g})$. This salt was recrystallized six times from acetone at $-5^{\circ}$ to give the quinine salt of $21(12.5 \mathrm{~g}$, $41 \%$ yield). This salt was treated as described in the previous example to give white crystalline needles: $5.6 \mathrm{~g}$, $40^{\circ} \%$ overall yield; m.p. $137.5-138.5^{\circ},[\alpha]_{\mathrm{D}}^{23}=-25.5^{\circ}$ (MeOH, $c=5 \mathrm{~g} / \mathrm{dl}$ ). 
Analysis. Calculated for $\mathrm{C}_{15} \mathrm{H}_{19} \mathrm{NO}_{4}: \mathrm{C}, 64.97 ; \mathrm{H}, 6.91 ; \mathrm{N}$, 5.05. Found: $\mathrm{C}, 64.95 ; \mathrm{H}, 6.85 ; \mathrm{N}, 4.88$.

\section{(-)-2-Methyl-S-pipecolic acid (20)}

(a) Hydrogen bromide method. A solution of $\mathrm{HBr}$ in acetic acid $(10 \mathrm{ml})$ was added dropwise to $18(2.0 \mathrm{~g}, 7.2 \mathrm{mmol})$ with stirring. The mixture was allowed to react for $30 \mathrm{~min}$ at room temperature. The reaction mixture was evaporated to dryness and the residue triturated with ethyl ether. The product precipitated as fine white crystals and was recrystallized from a methanol-ethyl ether mixture to give (-)-2-methyl-S-pipecolic acid hydrobromide salt (19) $\left(1.5 \mathrm{~g}, 93^{\circ} \%\right.$ yield $) ;$ m.p. $262-265^{\circ},[\alpha]_{\mathrm{D}}^{23}=-5.25(\mathrm{MeOH}$, $c=2 \mathrm{~g} / \mathrm{dl})$.

This hydrobromide salt was dissolved in water and passed through a column of Amberlite i.r.-45. The residue obtained after rotary evaporation of the water was crystallized from methanol-ethyl ether to give free amino acid $20(0.80 \mathrm{~g}, 85 \%$ yield); m.p. $350^{\circ}$ (sublimation).

(b) Catalytic hydrogenation method. A solution of 18 $(1.0 \mathrm{~g}, 3.6 \mathrm{mmol})$ in methanol $(50 \mathrm{ml})$ and catalytic amounts of platinum oxide was hydrogenated at $45 \mathrm{psi}$. When hydrogen uptake ceased $(8 \mathrm{hr})$ the solution was filtered, the filtrate was evaporated to dryness and the residue crystallized from methanol-ethyl ether to give colourless crystals $(0.50 \mathrm{~g}$, $98 \%$ yield); m.p. $350^{\circ}$ (sublimation), $[\alpha]_{D}^{23}=-3.7\left(\mathrm{H}_{2} \mathrm{O}\right.$, $c=2 \mathrm{~g} / \mathrm{dl}$ ).

Analysis. Calculated for $\mathrm{C}_{7} \mathrm{H}_{13} \mathrm{NO}_{2}: \mathrm{C}, 58.72 ; \mathrm{H}, 9.15 ; \mathrm{N}$, 9.78. Found: $\mathrm{C}, 58.76 ; \mathrm{H}, 9.19 ; \mathrm{N}, 9.82$.

NMR $(\mathrm{D}, \mathrm{O}) \delta:\left(\mathrm{CH}_{3}\right), 3.3-3.6(2 \mathrm{H}$, distorted $\mathrm{t})$, $\left(\mathrm{CH}_{2}\right)_{\beta, \gamma, \delta}: 1.8-2.7(6 \mathrm{H}, \mathrm{m}), \alpha-\mathrm{CH}_{3}, 1.7(3 \mathrm{H}, \mathrm{s})$.

I.R. (KBr): $3100-2300,1590-1620,1450,1395,1360$, $1295,1290,1210,1180,1115,1060,1045,1000,985,875,850$ and $780 \mathrm{~cm}^{-1}$.

\section{(+)-2-Methyl-R-pipecolic acid (23)}

Compound 23 was prepared in the same fashion as described for the $l$-rotatory isomer. (+)-2-Methyl-R-pipecolic acid hydrobromide (22) possessed the following properties: m.p. $261-263^{\circ},[\alpha]_{\mathrm{D}}^{23}=+5.1(\mathrm{MeOH}, c=2 \mathrm{~g} / \mathrm{dl})$. The free amino acid 23 had the following properties: m.p. 350 (sublimation), $[\alpha]_{\mathrm{D}}^{23}+5 \pm 2^{\circ}\left(\mathrm{H}_{2} \mathrm{O}, c=2 \mathrm{~g} / \mathrm{dl}\right)$.

Analysis. Calculated for $\mathrm{C}_{7} \mathrm{H}_{13} \mathrm{NO}_{2}: \mathrm{C}, 58.72 ; \mathrm{H}, 9.15 ; \mathrm{N}$, 9.78. Found: C, $58.75 ; \mathrm{H}, 9.09 ; \mathrm{N}, 9.80$.

The NMR and i.r. spectra are identical to those of the (-)-S-isomer 20.

\section{Methyl 1-benzyl-2-oxocyclopentanecarboxylate (2c)}

The procedure used for the preparation of methyl 1-methyl-2-oxocyclopentane was employed here. The benzylation of methyl 2-oxocyclopentane-carboxylate $(250 \mathrm{~g}$, $1.76 \mathrm{~mol})$ gave, after distillation, pure product $(330 \mathrm{~g}, 81 \%$ yield); b.p. $187^{\circ} / 23 \mathrm{mmHg}$.

Analysis. Calculated for $\mathrm{C}_{14} \mathrm{H}_{16} \mathrm{O}_{3}: \mathrm{C}, 72.39 ; \mathrm{H}, 6.94$

Found: C, 72.34; H, 6.90 .

NMR (neat) $\delta ; 7.25(5 \mathrm{H}, \mathrm{m}) ; 3.65(3 \mathrm{H}, \mathrm{s})$; benzylic $\left.-\mathrm{CH}_{2}-\mathrm{O}-\mathrm{S}\right) \mathrm{AB}$ pattern at 3.30 and $3.0\left(2 \mathrm{H}, \mathrm{J}_{\mathrm{AB}}=14 \mathrm{~Hz}\right)$; $2.6-1.5(6 \mathrm{H}, \mathrm{m})$.

\section{Methyl 2-benzyl-6-oxopipecolate (3c)}

The procedure used for the preparation of $\mathbf{3 a}$ was used except that methyl 2-oxocyclopentane-carboxylate was added dropwise to a solution of $\mathrm{HN}_{3}$ and $\mathrm{H}_{2} \mathrm{SO}_{4}$ in chloroform at -10 over a period of $3 \mathrm{hr}$. Crystalization of the product from ethyl acetate-hexane gave colourless crystals in $79 \%$ yield; m.p. 111-113

Analysis. Calculated for $\mathrm{C}_{14} \mathrm{H}_{17} \mathrm{NO}_{3}: \mathrm{C}, 68.00 ; \mathrm{H}, 6.93 ; \mathrm{N}$. 5.66. Found: $67.89 ; \mathrm{H}, 6.99 ; \mathrm{N}, 5.69$.

NMR $\left(\mathrm{CDCl}_{3}\right) \delta$ : Aromatic $7.2(5 \mathrm{H}, \mathrm{m})$, amide 6.5 $(1 \mathrm{H}, \mathrm{s})$, methyl ester $3.65(3 \mathrm{H}, \mathrm{s})$, benzylic AM pattern. $\mathrm{M}=3.25, \mathrm{~A}=2.87\left(2 \mathrm{H}, \mathrm{J}_{\mathrm{AM}}=14 \mathrm{~Hz}\right),\left(\mathrm{CH}_{2}\right)_{\beta, . ;} 2.45-1.40$ $(6 \mathrm{H}, \mathrm{m})$.
I.R. $(\mathrm{KBr}): 3190,3075,2960,1735,1660,1490,1450$, $1435,1400,1330-1300,1265,1240,1190,1095,1010,985$ and $830-690 \mathrm{~cm}^{-1}$.

\section{Methyl 2-benzylpipecolate (6c)}

The method of Borch [15] was used except that the reduction with sodium borohydride was carried out at $0^{\circ}$ for $6 \mathrm{hr}$ and continued at $25^{\circ}$ for an additional $12 \mathrm{hr}$. Methyl 2-benzyl-6-oxopipecolate $(130 \mathrm{~g}, 0.49 \mathrm{~mol})$ was reduced to give $6 \mathrm{c}(86.0,70 \%)$, as a viscous oil (b.p. $114 \% .25 \mathrm{mmHg}$ ) which crystallized upon standing; m.p. $39-40^{\circ}$.

Analysis. Calculated for $\mathrm{C}_{14} \mathrm{H}_{19} \mathrm{NO}_{2}: \mathrm{C}, 72.07 ; \mathrm{H}, 8.21 ; \mathrm{N}$, 6.00. Found: $\mathrm{C}, 71.92 ; \mathrm{H}, 8.00 ; \mathrm{N}, 6.12$.

NMR $\left(\mathrm{CDCl}_{3}\right) \delta:$ Aromatic $7.20(5 \mathrm{H}, \mathrm{m}), 3.60(3 \mathrm{H}, \mathrm{s})$, benzylic AB pattern 3.0-2.75 $\left(2 \mathrm{H}, \mathrm{J}_{\mathrm{AB}}=12 \mathrm{~Hz}\right)$, NH, 2.0 (1 H, s), $2.40-1.20(8 \mathrm{H}, \mathrm{m})$.

I.R. (neat): $3340,3040,2950,2870,1735,1610,1500$, $1450,1225-1175,1135,1100,1020,765$ and $710 \mathrm{~cm}^{-1}$.

\section{2-Benzylpipecolic acid $(\boldsymbol{8})$}

Compound $6 \mathrm{c}(80 \mathrm{~g}, 0.34 \mathrm{~mol})$ was suspended in $800 \mathrm{ml}$ I $\mathrm{N} \mathrm{NaOH}$ and refluxed for $2 \mathrm{hr}$. The clear solution was cooled to $70^{\circ}$ and acidified $(1 \mathrm{~N} \mathrm{HCl})$ with stirring using Congo red as an indicator; the free amino acid precipitated upon cooling to room temperature; it was collected by filtration and washed with excess water and dried. The free amino acid was insoluble in water or organic solvents (DMSO, MeOH) but was soluble in acidic or basic solution, yield $94 \%$; m.p. $360^{\circ}$ (dec).

Analysis. Calculated for $\mathrm{C}_{13} \mathrm{H}_{17} \mathrm{NO}_{2}: \mathrm{C}, 71.20 ; \mathrm{H}, 7.81 ; \mathrm{N}$, 6.39. Found: $\mathrm{C}, 71.92 ; \mathrm{H}, 8.00 ; \mathrm{N}, 6.12$

NMR $\left(\mathrm{D}_{2} \mathrm{O}-\mathrm{DCl}\right) \delta$ : Aromatic $7.40(5 \mathrm{H}, \mathrm{m})$, benzylic $3.23(2 \mathrm{H}, \mathrm{m}),\left(\mathrm{CH}_{2}\right)_{\mathrm{c}}: 3.25(2 \mathrm{H}, \mathrm{m}),\left(\mathrm{CH}_{2}\right)_{\beta, ;, \delta}: 2.65-1.50$ $(6 \mathrm{H}, \mathrm{m})$.

I.R.: $3450,3110,3030,2970,2930,2860,2500-2400,1615$. $1595,1450,1425,1390,1345,1330,1310,1280,1235,1185$. $1100,870,850,750$ and $710 \mathrm{~cm}^{-1}$.

\section{6-Methylpicolinic acid (9)}

The method of Black, Depp and Corson [18] was used for the partial oxidation of 2,6-lutidine.

\section{Ethyl 6-methylpicolinate (10)}

A solution of $9(200 \mathrm{~g}, 1.46 \mathrm{~mol})$ in absolute ethanol $(1000 \mathrm{ml})$ was saturated with $\mathrm{HCl}$ gas, and allowed to reflux for $2 \mathrm{hr}$. The solvent was evaporated, the residue was washed with cold aqueous potassium carbonate, and extracted with ether. The extracts were dried $\left(\mathrm{MgSO}_{4}\right)$, filtered, evaporated, and the ester was distilled under vacuum. yielding $217 \mathrm{~g}(90 \%)$ of pure colourless liquid; b.p. $125 / 20 \mathrm{mmHg}$ (lit. [17] 79-81\%0.25 mmHg).

NMR (neat) $\delta$ : Aromatic $7.95(2 \mathrm{H}, \mathrm{m}), 7.40(1 \mathrm{H}, \mathrm{m})$, ethyl ester, $4.45(2 \mathrm{H}, 9), 1.40(3 \mathrm{H}, \mathrm{t}), 6$-methyl $2.60(3 \mathrm{H}, \mathrm{s})$.

\section{Methyl 6-methylpicolinate (12)}

The esterification procedure described above was not successful, instead the methyl ester was obtained in $46^{\circ} \%$ yield when thionyl chloride [17] was used; b.p. $62^{\circ} / 10 \mathrm{~mm}$. Analysis. Calculated for $\mathrm{C}_{8} \mathrm{H}_{9} \mathrm{NO}_{2}: \mathrm{C}, 63.56 ; \mathrm{H}, 6.00 ; \mathrm{N}$, 6.27. Found: C, 63.54; H, 6.15; N, 9.24

NMR (neat) $\delta$ : Aromatic $7.85(2 \mathrm{H}, \mathrm{m}), 7.40(1 \mathrm{H}, \mathrm{m})$, methyl ester $4.03(3 \mathrm{H}, \mathrm{s}), 6$-methyl $2.62(3 \mathrm{H}, \mathrm{s})$.

\section{Ethyl cis-6-methylpipecolate (11)}

The catalytic hydrogenation of 10 was carried out according to the literature [17]; b.p. $58-60 \% / 10 \mathrm{mmHg}$ (lit. [17] $99-100 / 13 \mathrm{~mm}$ ). The product was analyzed by gas chromatography with three different columns (Chrom W deg, Propak $P$, and $\mathrm{C}_{\mathrm{w}} \mathrm{A}_{\mathrm{w}}$-DMCS); it was found that the ethyl ester is pure cis isomer.

NMR $\left(\mathrm{CDCl}_{3}\right) \delta$ : Ethyl ester $4.10(2 \mathrm{H}, 9), 1.15(3 \mathrm{H}, \mathrm{t})$, $(\mathrm{CH})_{x}: 3.30(1 \mathrm{H}, \mathrm{m}),(\mathrm{CH}) 2.60(1 \mathrm{H}, \mathrm{m})$, NH $2.05(1 \mathrm{H}, \mathrm{s})$, $\left(\mathrm{CH}_{3}\right)_{x}: 1.05(3 \mathrm{H}, \mathrm{d}, \mathrm{J}=6 \mathrm{~Hz}),\left(\mathrm{CH}_{2}\right)_{\beta ;, \gamma} 1.0-2.0(6 \mathrm{H}, \mathrm{m})$. 


\section{Methyl 6-methylpipecolates $(13,14)$}

Compound 12 ( $28 \mathrm{~g}, 0.185 \mathrm{~mol}$ ), $400 \mathrm{ml}$ methanol (containing $2.5 \% \mathrm{HCl}$ gas), and platinum oxide $(2.5 \mathrm{~g}$ ) were mixed and hydrogenated at $40 \mathrm{psi}$ at room temperature for $12 \mathrm{hr}$. The purification was carried out as described in the previous example. A mixture of methyl cis- and trans-6methyl pipecolate was obtained $(16 \mathrm{~g}, 55 \%$ yield $)$; b.p. $47^{\circ} / 10 \mathrm{mmHg}$. The composition of this mixture was found by gas chromatography (using Chrom W OF-1) to be $87 \%$ cis and $13 \%$ trans) with retention times of $1^{\prime} 30^{\prime \prime}$ and $2^{\prime} 20^{\prime \prime}$, respectively.

Analysis. Calculated for $\mathrm{C}_{8} \mathrm{H}_{15} \mathrm{NO}_{2}: \mathrm{C}, 61.51 ; \mathrm{H}, 9.03 ; \mathrm{N}$ 8.97. Found: C, 61.42; H, 9.06; N, 8.94.

NMR (neat) $\delta$ : Methyl ester $3.60(3 \mathrm{H}, \mathrm{s}),(\mathrm{CH})_{\alpha}: 3.20$ $(1 \mathrm{H}, \mathrm{m}),(\mathrm{CH})_{1}: 2.50(1 \mathrm{H}, \mathrm{m}),\left(\mathrm{CH}_{2}\right)_{\beta, \gamma} . \dot{0} 1.90-0.90(6 \mathrm{H}, \mathrm{m})$, $\left(\mathrm{CH}_{3}\right)_{\mathrm{a}}: 1.00($ cis, d, J =6 Hz), 0.98 (trans, d, J =6 Hz).

\section{Cis-6-methylpipecolic acid hydrochloride (16)}

A solution of $11(20 \mathrm{~g}, 0.117 \mathrm{~mol})$ in $100 \mathrm{ml} 2 \mathrm{~N} \mathrm{HCl}$ solution was refluxed for $2 \mathrm{hr}$. The solvent was evaporated to dryness and the residue was crystallized from methanol-ether $\left(14 \mathrm{~g}\right.$, yield $56 \%$ ), m.p. $262^{\circ}$.

Analysis. Calculated for $\mathrm{C}_{7} \mathrm{H}_{14} \mathrm{ClNO}_{2}: \mathrm{C}, 46.80 ; \mathrm{H}, 7.85$; $\mathrm{N}, 7.80$. Found: $\mathrm{C}, 46.74 ; \mathrm{H}, 7.77 ; \mathrm{N}, 7.82$.

NMR $\left(\mathrm{D}_{2} \mathrm{O}\right) \delta:(\mathrm{CH})_{z}: 4.0(1 \mathrm{H}, \mathrm{m}),(\mathrm{CH})_{\mathrm{r}}: 3.30(1 \mathrm{H}, \mathrm{m})$, $\left(\mathrm{CH}_{2}\right)_{\beta, \gamma}$ 2.6-1.4 $(5 \mathrm{H}, \mathrm{m}),\left(\mathrm{CH}_{3}\right)_{\ell}: 1.36(3 \mathrm{H}, \mathrm{d}, \mathrm{J}=6 \mathrm{~Hz})$.

\section{Cis-6-methylpipecolic acid (15)}

Compound $11(150 \mathrm{~g}, 0.88 \mathrm{~mol})$ was suspended in water $(1000 \mathrm{ml})$ and refluxed for $6 \mathrm{hr}$. Water was evaporated and the dry residue was crystallized from ethanol-ether, yielding 110 g (88\%), m.p. $252-253^{\circ}$ (dec).

Analysis. Calculated for $\mathrm{C}_{7} \mathrm{H}_{13} \mathrm{NO}_{2}: \mathrm{C}, 58.72 ; \mathrm{H}, 9.14 ; \mathrm{N}$, 9.78. Found: $\mathrm{C}, 58.77 ; \mathrm{H}, 9.12 ; \mathrm{N}, 9.78$.

NMR $\left(\mathrm{D}_{2} \mathrm{O}\right) \delta:(\mathrm{CH})_{\alpha}$ and $(\mathrm{CH})_{\mathrm{c}} 4.0-3.0(2 \mathrm{H}, \mathrm{m})$, $\left(\mathrm{CH}_{2}\right)_{\beta, \delta .} 2.4-1.3(6 \mathrm{H}, \mathrm{m}),\left(\mathrm{CH}_{3}\right)_{x}: 1.32(3 \mathrm{H}, \mathrm{d}, \mathrm{J}=6 \mathrm{~Hz})$.

I.R. $(\mathrm{KBr}): 3450-2500,1610,1480,1400,1380,1160$, $1050,1000,770$ and $690 \mathrm{~cm}^{-1}$.

\section{$\mathrm{N}$-carbobenzoxy-cis-6-methylpipecolic acid (24)}

A solution of $15(10.0 \mathrm{~g}, 0.07 \mathrm{~mol})$ in $17.5 \mathrm{ml} 4 \mathrm{~N} \mathrm{NaOH}$ was chilled to $0-5$. $\mathrm{NaOH}(21 \mathrm{ml}, 4 \mathrm{~N})$ and benzylchloroformate $(13.0 \mathrm{~g}, 0.076 \mathrm{~mol})$ were alternately added in portions over a period of $30 \mathrm{~min}$ with stirring. The reaction mixture was stirred for one additional hour, extracted with ether to remove excess acid chloride and the aqueous fraction was acidified carefully using Congo red as the indicator, with $5 \mathrm{~N} \mathrm{HCl}$ and cooling in an ice bath. The separated oily substance was extracted with ethyl acetate and dried $\left(\mathrm{MgSo}_{4}\right)$. Ethyl acetate was removed and the oily residue was crystallized from ethyl acetate-hexane to give $13.0 \mathrm{~g}(67 \%$ yield $)$ of white crystals; m.p. $80^{\circ}$

Analysis. Calculated for $\mathrm{C}_{15} \mathrm{H}_{19} \mathrm{NO}_{4}: \mathrm{C}, 64.96 ; \mathrm{H}, 6.91 ; \mathrm{N}$, 5.05. Found: C, 64.92; H, 6.83; N, 4.98 .

NMR $\left(\mathrm{CDCl}_{3}\right) \delta$ : Aromatic protons, $7.40(5 \mathrm{H}, \mathrm{s})$; benzylic protons, $5.20(2 \mathrm{H}, \mathrm{s}) ; \mathrm{CH}_{\alpha} 4.90(1 \mathrm{H}, \mathrm{m}) ; \mathrm{CH}_{4} 4.40$ $(1 \mathrm{H}, \mathrm{m}) ; \quad\left(\mathrm{CH}_{2}\right)_{\beta, \gamma} \quad 1.50-2.20 \quad(6 \mathrm{H}, \mathrm{m}) ; \mathrm{CH}_{2} \quad 1.2$ $(3 \mathrm{H}, \mathrm{d}, \mathrm{J}=6 \mathrm{~Hz})$; COOH $11.15(1 \mathrm{H}, \mathrm{s})$.

\section{$\mathrm{N}$-(4-phenylbenzyloxycarbonyl)-cis-6-methylpipecolic acid (26)}

Compound 25 was prepared from 4-biphenylmethanol and phosgene by a procedure similar to that for the preparation of benzyl chloroformate [20] $(92 \%$ yield). A solution of $15(26.0 \mathrm{~g}, 0.18 \mathrm{~mol})$ in $45 \mathrm{ml} 4 \mathrm{~N} \mathrm{NaOH}$ was mixed with $200 \mathrm{ml}$ of dioxane-water ( $50: 50$ by vol.). The mixture was cooled to $5^{\circ} ; 45 \mathrm{ml} 4 \mathrm{~N} \mathrm{NaOH}$ and a solution of $47.0 \mathrm{~g}(0.19 \mathrm{~mol})$ of crude $25 \mathrm{in} 60 \mathrm{ml}$ dioxane were added alternately to the cooled reaction mixture with vigorous stirring. When the addition was completed $(0.5 \mathrm{hr})$ the reaction mixture was stirred for an additional $3 \mathrm{hr}$, keeping the temperature between 0 and $5^{\circ}$. The suspension was extracted 3 times with ethyl ether and once with ethyl acetate to remove the unreacted chloroformate derivative, dioxane and di-(4-phenylbenzyl)-carbonate formed as a side product. The aqueous layer was acidified with $5 \mathrm{~N} \mathrm{HCl}$ to $\mathrm{pH} 4.0$ and extracted with chloroform. The organic extracts were dried $\left(\mathrm{MgSO}_{4}\right)$; filtration and evaporation of the solvent afforded $47.5 \mathrm{~g}(74 \%)$ of a viscous oil. Several attempts to crystallize the oily product were not successful. The compound was used directly in the following step, since its NMR indicated high purity.

NMR $\left(\mathrm{CDCl}_{3}\right) \delta:$ COOH $11.0(1 \mathrm{H}, \mathrm{s})$; aromatic 7.7-7.2 $(9 \mathrm{H}, \mathrm{m}) ; \mathrm{ArCH}_{2} 5.2(2 \mathrm{H}, \mathrm{s}) ; \mathrm{CH}_{\alpha} 4.9(1 \mathrm{H}, \mathrm{m}) ; \mathrm{CH}_{\mathrm{f}} 4.4$ $(1 \mathrm{H}, \mathrm{m}) ;\left(\mathrm{CH}_{2}\right)_{\beta, \gamma, \delta} 2.3-1.4(6 \mathrm{H}, \mathrm{m}) ; \mathrm{CH}_{3} 1.20(3 \mathrm{H}, \mathrm{d}, \mathrm{J}=$ $6 \mathrm{~Hz})$

(-)-N-(4-Phenylbenzyloxycarbonyl)-cis-6-methyl-S-pipecolic acid (27)

Compound $26(48.0 \mathrm{~g}, 0.133 \mathrm{~mol})$ and quinine $(43.2 \mathrm{~g}$, $0.133 \mathrm{~mol}$ ) were dissolved in $500 \mathrm{ml}$ methanol and refluxed for $30 \mathrm{~min}$. Solvent was evaporated under aspirator pressure and the residue was dissolved in hot toluene $(450 \mathrm{ml})$. The clear solution was slowly cooled to $-5^{\circ}$ and allowed to crystallize for $24 \mathrm{hr}$. A white crystalline salt $(40.0 \mathrm{~g})$ was collected by filtration and recrystallized seven times from a mixture of acetone-water (90:10, by volume). The quinine salt of the $l$-rotatory acid was thus obtained $(12.0 \mathrm{~g}, 27 \%$ yield); m.p. $163-164^{\circ},[\alpha]_{\mathrm{D}}^{25}=-110.7^{\circ}(\mathrm{MeOH}, c=2 \mathrm{~g} / \mathrm{dl})$. Analysis. Calculated for $\mathrm{C}_{41} \mathrm{H}_{47} \mathrm{~N}_{3} \mathrm{O}_{6}: \mathrm{C}, 72.65 ; \mathrm{H}, 6.99$; $\mathrm{N}, 6.20$. Found: $\mathrm{C}, 72.63 ; \mathrm{H}, 6.96 ; \mathrm{N}, 6.28$.

An aqueous solution of $\mathrm{NH}_{3}(100 \mathrm{ml} 2 \mathrm{~N})$ was added dropwise to a chloroform solution of the above quinine salt $\left(11.0 \mathrm{~g}, 16 \mathrm{mmol}\right.$ in $\left.100 \mathrm{ml} \mathrm{CHCl}_{3}\right)$ with cooling and stirring. The chloroform was evaporated; the aqueous solution was extracted with ether to remove the free quinine, acidified to a pH of 4.0 with $2 \mathrm{~N} \mathrm{HCl}$, and extracted with chloroform. The chloroform layer was dried $\left(\mathrm{MgSO}_{4}\right)$ and the solvent was evaporated. The foamy residue was crystallized by slow evaporation of chloroform-hexane solution to give $5.2 \mathrm{~g}$ $(94 \%)$ of white crystals, m.p. $99-100^{\circ},[\alpha]_{\mathrm{D}}^{25}-31.9(\mathrm{MeOH}$, $c=2 \mathrm{~g} / \mathrm{dl}$ ).

Analysis. Calculated for $\mathrm{C}_{21} \mathrm{H}_{23} \mathrm{NO}_{4}: \mathrm{C}, 71.37 ; \mathrm{H}, 6.56 ; \mathrm{N}$, 3.96. Found: C, $71.32 ; \mathrm{H}, 6.67 ; \mathrm{N}, 3.88$.

The NMR spectrum was identical to that of the racemic compound.

I.R. (KBr): 3140, 3095, 3060,3030, 2980, 2950, 1735 , $1665,1490,1450,1430,1410,1385,1360,1345,1335,1315$, $1290,1210,1160,1135,1110,1080,1045,1010,970,950$, $870,830,800,780,760$ and $700 \mathrm{~cm}^{-1}$.

\section{(-)-cis-6-methyl-S-pipecolic acid (28)}

Compound $27(1.1 \mathrm{~g}, 3.1 \mathrm{mmol})$ in $20 \mathrm{ml}$ methanol was hydrogenated by a procedure similar to that for the preparation of 2-methyl-S-pipecolic acid. The free amino acid was crystallized from ethanol-ether, yielding $0.4 \mathrm{~g}(90 \%)$; m.p. $272-274^{\circ}(\mathrm{dec}),[\alpha]_{D}^{23}=-14.9^{\circ}(\mathrm{MeOH}, c=1.5 \mathrm{~g} / \mathrm{dl})$.

Analysis. Calculated for $\mathrm{C}_{7} \mathrm{H}_{13} \mathrm{NO}_{2}: \mathrm{C}, 58.72 ; \mathrm{H}, 9.15 ; \mathrm{N}$, 9.78. Found: C, $58.75 ; \mathrm{H}, 9.09 ; \mathrm{N}, 9.69$.

\section{RESULTS AND DISCUSSION}

\section{Syntheses of 2-benzyl-and 2-methylpipecolic acids}

$(-)$ S-pipecolic acid is a naturally occurring amino acid present in the fruit of beans and other legumes [9]. Pipecolic acid was shown to be formed from lysine by plants and subsequently was implicated in lysine metabolism by mammals [10]. Various methods for its synthesis are detailed by Greenstein and Winitz [11]. Katchalski et al. [12] have reported on the properties of poly-S-pipecolic acid.

The only 2-alkylpipecolic acid reported previously is pipecolic acid [13]. A convenient and general 

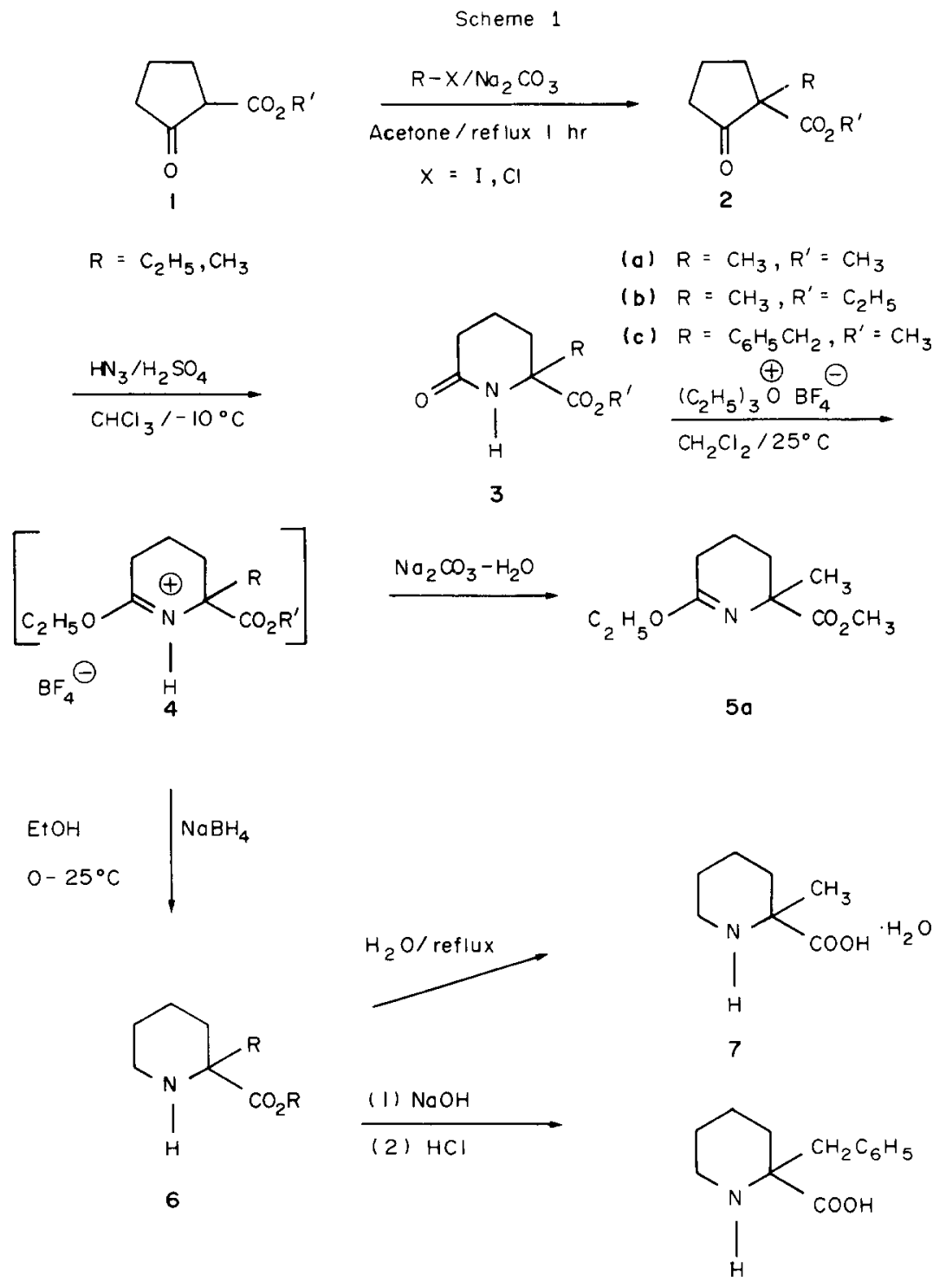

8

approach for the preparation of 2-alkylpipecolic acids is outlined in Scheme 1. Alkyl 2-oxocyclopentanecarboxylates (1) were alkylated in situ according to the method of Claisen as simplified by Barco et al. [14]. C-alkylation was quantitative and the yields of the distilled products were $81 \%$ for benzylation and $97 \%$ for methylation. A Schmidt reaction was utilized for ring enlargement, using conc. sulphuric acid as catalyst and 1.3 equivalents of hydrazoic acid in dry chloroform at $-10^{\circ}$. These conditions gave oxopipecolate 3 in $67-79 \%$ yield. The selective reduction of the amide group in 3 is best accomplished by the method of Borch [15], using triethyloxonium tetrafluoroborate [16] directly to convert the secondary amide (3) to the iminoether fluoroborate salt (4). This was reduced directly with sodium borohydride to give alkyl 2-alkylpipecolate (6) in an overall yield of $67-73 \%$ from 3 . The free imino ether $(\mathbf{5} \boldsymbol{a})$ was obtained by neutralizing its salt (4a) with cold aqueous sodium carbonate. Hydrolysis of $\mathbf{6 a}$ or $\mathbf{6 b}$ was accomplished in water at reflux; whereas, $\mathbf{6 c}$ required base catalyzed hydrolysis. 2-Methylpipecolic acid (7) was obtained (94\% yield) in its monohydrate form upon crystallization from $70 \%$ aqueous ethanol. 2-Benzylpipecolic acid (8) was obtained upon acidifying its sodium salt solution. The free amino acid $\mathbf{8}$ is insoluble in water and precipitated from the solution as a white solid. It is soluble only in water at high or low pHs. 2-Methylpipecolic acid is soluble in water, hot $70 \%$ aqueous ethanol, and hot DMSO, slightly soluble in hot ethanol and insoluble in chloroform, acetone or cold ethanol.

\section{Synthesis of cis-6-methylpipecolic acid}

6-Methylpipecolic acid has previously been synthesized but no indication was given about its stereochemistry [17]. 2,6-Lutidine was partially oxidized (see Scheme 2) to give 6-methylpicolinic acid (9) according to the literature [18]. Ethyl 6-methylpico- 
<smiles>Cc1cccc(C)n1</smiles><smiles>CC(C)CCOCCO</smiles><smiles>Cc1cccc(C(=O)O)n1</smiles>
9<smiles>CCOC(=O)c1cccc(C)n1</smiles><smiles>COC(=O)c1cccc(C)n1</smiles>

12<smiles>CC(=O)OC1CCCC(C)N1</smiles>

$13 \quad 87 \%$<smiles>CC1CCCC(C(=O)O)N1</smiles>

15<smiles>CC(=O)[C@H]1CCCC(C)N1</smiles>

14
11

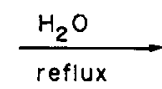

crystallized from acetone at $+5^{\circ}$. The less soluble salt $[(+) \mathrm{A} \cdot(-) \mathrm{Q}]$ was crystallized and purified further by three recrystallizations from acetone at $+5^{\circ}$. The free acid was liberated by treatment with ammonia with subsequent acidification. (+)-S- $N$-carbobenzoxy-2methylpipecolic acid (18) was obtained in $54 \%$ overall yield, based on one enantiomer, $[\alpha]_{D}^{23}+25.4^{\circ}$ $(\mathrm{MeOH})$. The carbobenzoxy group was removed either by catalytic hydrogenation or by acidic cleavage with hydrogen bromide. (-)-S-2-methylpipecolic acid hydrobromide (19) and the free amino acid were obtained with $[\alpha]_{D}^{23}-5.25^{\circ}(\mathrm{MeOH})$ and $-3.7^{\circ}$ $\left(\mathrm{H}_{2} \mathrm{O}\right)$, respectively. The filtrate of the initial crystallization of the diastereomeric salts was determined to be enriched with the $[(-) \mathrm{A} \cdot(-) \mathrm{Q}]$ salt. It was evaporated to dryness and recrystallized six times at $-5^{\circ}$ from acetone. Dissociation of this salt with ammonia followed by acidification produced (-)-R$N$-carbobenzoxy-2-methylpipecolic acid (21) in $41 \%$ of the theoretical yield for one enantiomer; $[\alpha]_{D}^{23}$ $-25.5^{\circ}(\mathrm{MeOH}) .(+)-\mathrm{R}-2$-methylpipecolic acid hydrobromide (22) and the free amino acid (23) had $[\alpha]_{0}^{23}+5.1^{\circ}(\mathrm{MeOH})$ and $5 \pm 2^{\circ}\left(\mathrm{H}_{2} \mathrm{O}\right)$, respectively. The specific rotations of all enantiomeric compounds in Scheme 3 are of comparable values with opposite signs of rotation, indicating high efficiency of the resolution.

\section{Resolution of cis-6-methylpipecolic acid}

We have made several attempts to resolve 6-methylpipecolic acid or its ethyl ester by means of fractional crystallization of the corresponding dipure 17. Resolution then proceeded according Scheme 3. The quinine salt of 17 was prepared and 




astereomeric salts but none of these attempts were successful. Several diastereoisomeric salts were prepared by treating $N$-carbobenzoxy-cis-6-methylpipecolic acid with an optically active resolving agent such as tyrosine hydrazide, ephedrine, quinine or brucine. Several solvents or solvent combinations with variable polarities were used in an attempt to crystallize these salts, but unfortunately not one of these was crystallizable. In most cases the salt separated from it solution as an oil upon cooling.

Eventually, we decided on 4-phenylbenzyloxycarbonyl as protecting group, due to its enhanced proclivity towards crystallization. 4-Phenylbenzyl chloroformate (25) was prepared in $92 \%$ yield from the reaction of phosgene with 4-biphenylmethanol by a procedure similar to that for the preparation of benzyl chloroformate [20]. Compound 25 was reacted with $c 6 \mathrm{MPA}$ in a dioxane-water $(1: 1)$ mixture. Dioxane was used as co-solvent in order to dissolve the solid chloroformate derivative 23. $N$-(4-phenylbenzyloxycarbonyl)-cis-6-methylpipecolic acid (26) was obtained as a viscous oil in $74 \%$ yield.

The quinine salt of compound 26 was formed in methanol (Scheme 4). It could be fractionally crystallized from toluene at $-5^{\circ}$. The crystals were recrystallized seven times from a mixture of acetonewater $(9: 1, v / v)$ at $-5^{\circ}$, to give the quinine salt of the $l$-rotatory acid $[(-) \mathrm{A} \cdot(-) \mathrm{Q}]$ in $27 \%$ yield based on one enantiomer, $[\alpha]_{\mathrm{D}}^{25}=-110.7^{\circ}(\mathrm{MeOH})$. Treating this salt with ammonia followed by acidification gave the $l$-rotatory acid $(27)$ in $94 \%$ yield, $[\alpha]_{D}^{23}=-12.5^{\circ}$ $(\mathrm{MeOH})$. The removal of the protecting group by catalytic hydrogenation afforded (-)-cis-6-methylS-pipecolic acid $(\mathbf{2 8})$ in $90^{\circ} \%$ yield, $[\alpha]_{\mathrm{D}}^{25}=-14.9^{\circ}$ $\left(\mathrm{H}_{2} \mathrm{O}\right)$.

The filtrate retained from the first crystallization in toluene was evaporated to dryness. The residue contained the quinine salts of the $d$-rotatory acid and 


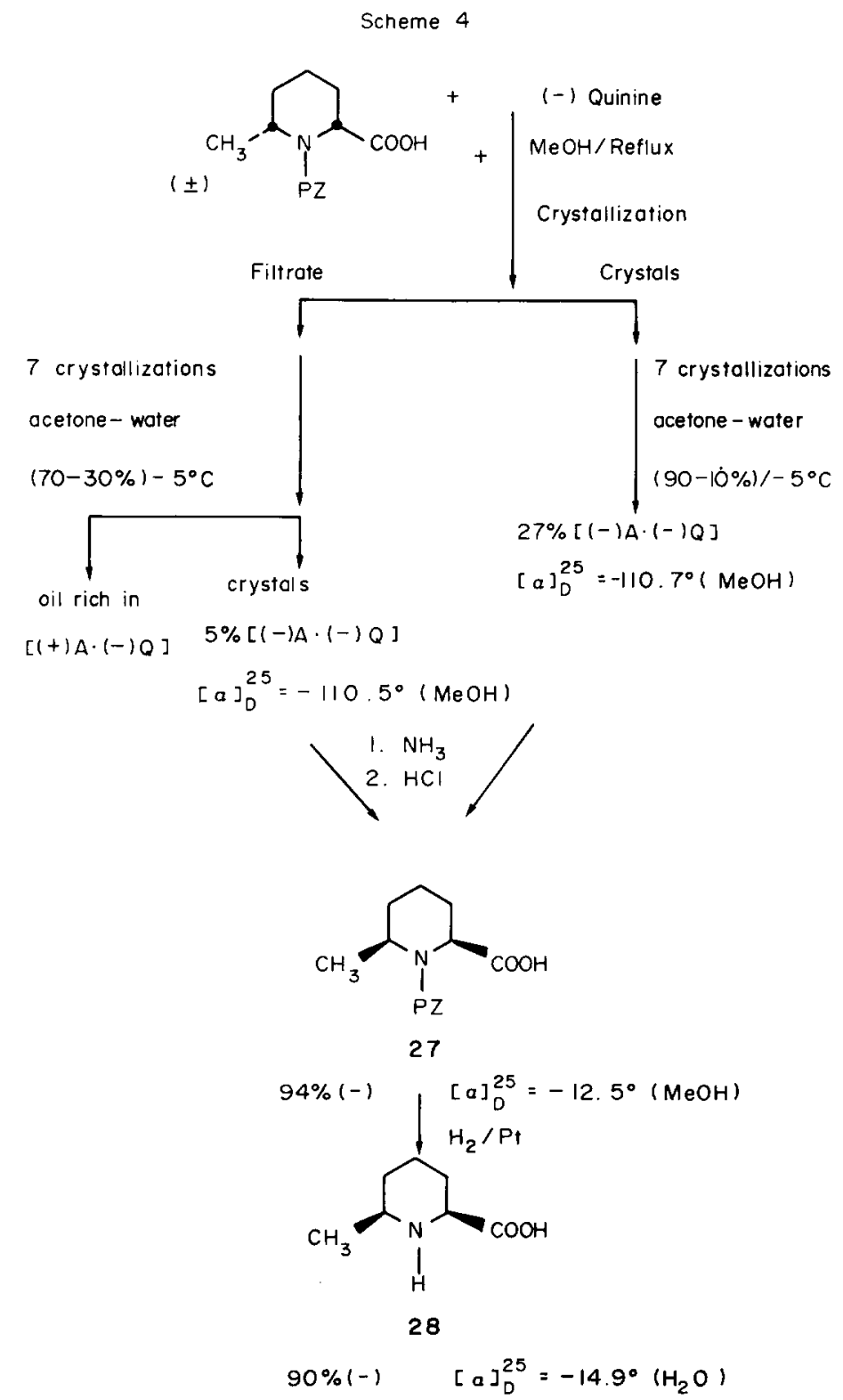

Scheme 5

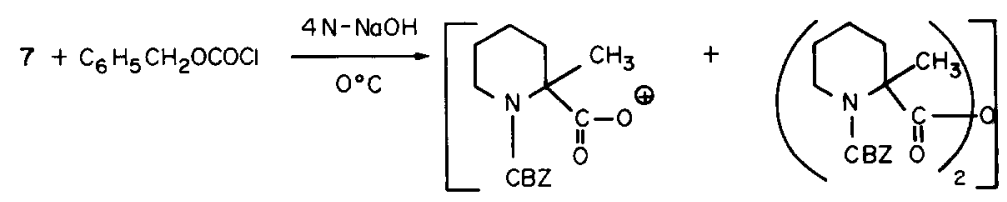

$\frac{\text { (1) } \mathrm{H}_{2} \mathrm{O} \text { /reflux }}{\text { (2) } \mathrm{HCl}}$<smiles>CC(C)(C(=O)O)N1CCCCC1(C)C(=O)O</smiles> 
Scheme 6
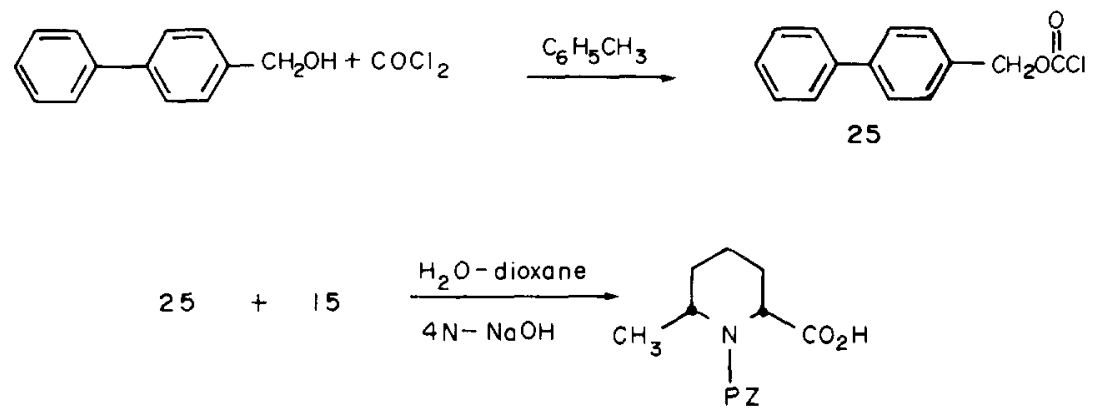

26

some of the $l$-rotatory acid. An attempt to crystallize this residue from a mixture of acetone-water $(7: 3, v / v)$ gave only the minor isomer as a crystalline salt in $5 \%$ yield. The quinine salt of the $d$-rotatory acid separated as an oil from the hot acetone-water solution upon cooling to room temperature. No further attempt was made to purify the $d$-rotatory acid.

\section{Absolute configurations}

Optical rotatory dispersion (ORD) and circular dichroism (CD) can be used for a rapid assignment of the absolute configuration of $\alpha$-amino acids [2,21-23]. All naturally-occurring and most synthetic $\alpha$-amino acids show positive Cotton effects around $200 \mathrm{~nm}$ in water and 208-210 in acid.

Figure 1 shows the CD spectra of (-)S-pipecolic acid (S-PA) (-)c6MPA, (-)2MPA, (-)S-proline (S-P) and (-)-2-methyl-S-proline (2M-S-P) in water and in acid. The $C D$ data are given in Table 1 as measured from Fig. 1. S-PA and $(-) c 6$ MPA each exhibits a single positive Cotton effect in water and in acid around $207-208 \mathrm{~nm}$. The similarity of their CD curves suggests that both compounds possess the

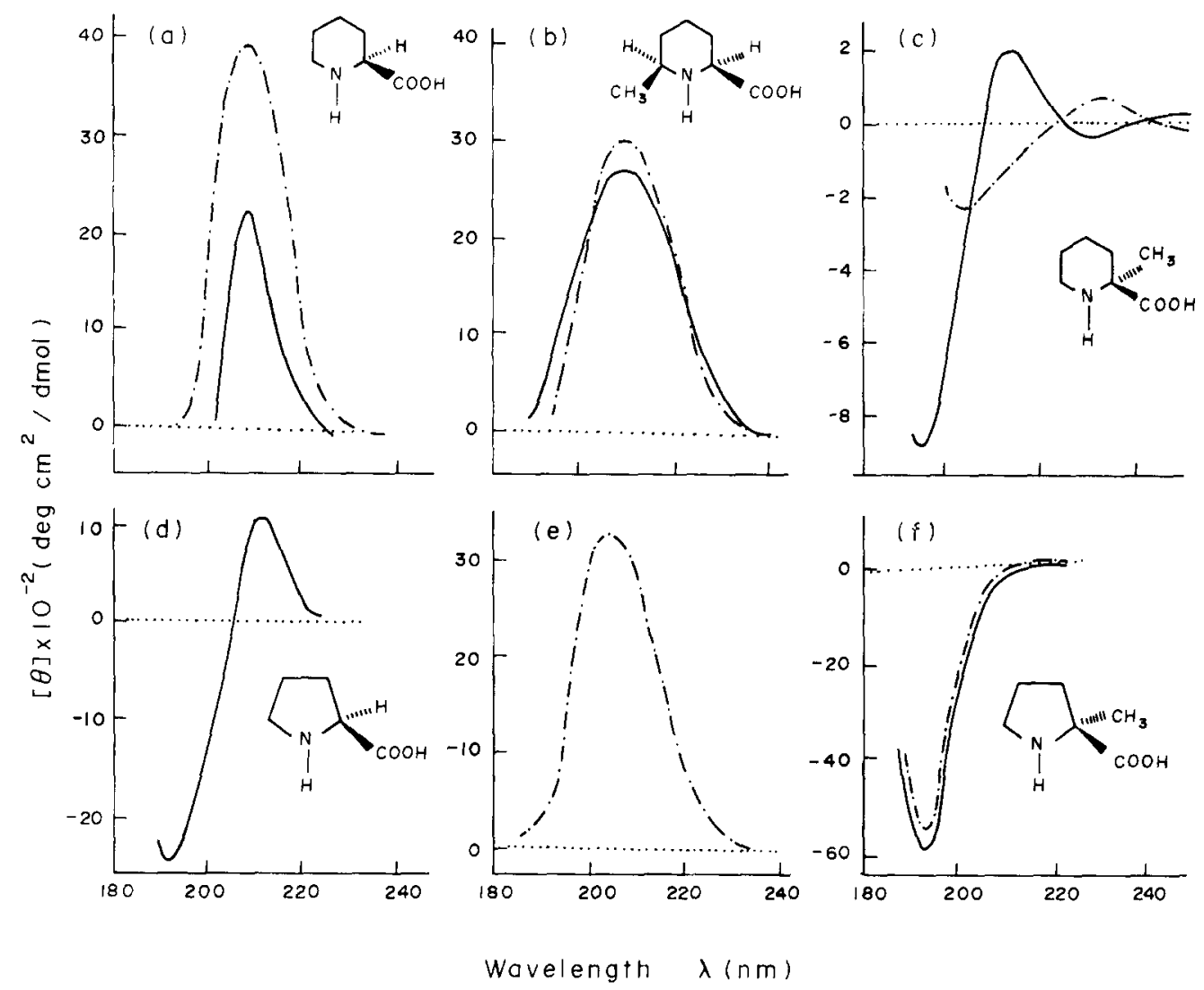

Fig. 1. CD Spectra of (a) (-)-S-pipecolic acid; (b) (-)-cis-6-methyl-S-pipecolic acid; (c) (-)-2methyl-S-pipecolic acid; (d) and (e) (-)-S-proline; (f) (-)-2-methyl-S-proline in water $(-)$ and in $1 \mathrm{~N}$ $\mathrm{HCl}$ solution $(-.-)$. 
Table 1. CD data of pipecolic acid, proline and related imino acids

\begin{tabular}{lcccc}
\hline & \multicolumn{2}{c}{$\mathrm{H}_{2} \mathrm{O}$} & \multicolumn{2}{c}{$\mathrm{HCl}$} \\
\cline { 2 - 4 } Compound & $\begin{array}{c}{[\theta] \times 10^{-2}} \\
(\mathrm{deg} \mathrm{cm} / \mathrm{dmol})\end{array}$ & $(\mathrm{nm})$ & $\begin{array}{c}{[\theta] \times 10^{-2}} \\
\left(\mathrm{deg} \mathrm{cm}^{2} / \mathrm{dmol}^{2}\right)\end{array}$ & $(\mathrm{nm})$ \\
\hline (-)-S-pipecolic acid & +21.20 & 207 & +39.30 & 208 \\
(-)-Cis-6-methyl-S-pipecolic acid & +27.90 & 207 & +30.10 & 207 \\
(-)-2-Methyl-S-pipecolic acid & -0.60 & 230 & +0.50 & 231 \\
& +1.85 & 212 & & \\
& -8.85 & 195 & -2.30 & 202 \\
(-)-S-proline & +9.80 & 211 & +31.00 & 207 \\
& -24.60 & 193 & - & - \\
(-)-2-Methyl-S-proline & -58.50 & 195 & -55.00 & 195 \\
\hline
\end{tabular}

$\mathrm{S}$ configuration. The CD spectrum of $(-) 2 \mathrm{MPA}$ in water shows three Cotton effects, a negative one at $195 \mathrm{~nm}$, a positive one at $212 \mathrm{~nm}$ and another negative one at $230 \mathrm{~nm}$, whereas the CD spectrum in acid shows only negative and positive Cotton effects at 202 and $231 \mathrm{~nm}$.

Two Cotton effects have been observed in water for S-azetidine-2-carboxylic acid, S-proline and 4methyl-S-proline [23] and three Cotton effects were reported for the CD spectrum of S-proline methyl ester [24]. More than one Cotton effect may arise from different conformations of the molecules [25], from different states of solvation [26], from the existence of "allowed" and "forbidden" transitions of closely similar energy levels [27], or from a combination of these factors [23]. Craig and Pereira [24] suggest that the three Cotton effects observed for proline methyl ester may be due to an optically active $n \rightarrow \sigma^{*}$ transition of the nitrogen for the positive CD band at $202 \mathrm{~nm}, n \rightarrow \pi^{*}$ transiton of the ester carbonyl group for the positive CD band at $209 \mathrm{~nm}$, and an interaction through space between the nonbonding orbital of the nitrogen atom and the chromophoric transition of the carbonyl group for the negative weak $C D$ band at $232 \mathrm{~nm}$. However, only one Cotton effect was observed in the CD spectra of the above compounds in acidic solutions around 208-212 nm [23, 24].

The S-configuration can be assigned to (-)2MPA based on the similarity of its CD spectra in water with that of proline and other related amino acids [23]. However, we have as yet no satisfactory explanation for the abnormal CD spectrum in acid of ( -2 MPA.

The sector rule of Jorgensen [28], which relates the sign and amplitude of the Cotton effect to the conformation and absolute configuration of $\alpha$-amino acids, can be applied here. His sector diagram is being referred to in the following discussion. The slightly higher positive rotation of pipecolic acid over proline can be attributed to the different geometry of the six-membered ring versus the five-membered ring. The $\mathrm{C}_{\beta}$ and $\mathrm{C}_{\epsilon}$ methylene groups in pipecolic acid are closer to the positive and negative sectors, respectively, than the corresponding $\mathrm{C}_{\beta}$ and $\mathrm{C}_{\delta}$ methylene groups in proline. Therefore, the net effect is a larger positive contribution. The Cotton effect of $(-) c 6 \mathrm{MPA}$ is more positive than that of S-PA in water; the methyl group is residing in the null sector as determined from an examination of the molecular model, thus creating a more positive value by decreasing the negative contribution to the net rotation.
Similar results have been found for cis-5-methylproline [2].

The sector rule of Jorgensen does not provide a satisfactory explanation for the observed $\mathrm{CD}$ spectra of (-)2MPA or (-)S-2MP. The CD spectrum of the latter shows a single negative Cotton effect at $195 \mathrm{~nm}$. The absolute configuration of $(-) 2 \mathrm{MP}$ was assigned the S-configuration [3] based on the method of Lutz-Jirgensons [29]. However, the sector rule predicts opposite configuration for $(-) 2 \mathrm{MP}$, namely the R-configuration. In the case of (-)2MPA the sector rule predicts a single positive Cotton effect with higher amplitude than that of S-PA because of the presence of an $\alpha$-methyl group in or nearby the positive sector. The experimental result does not agree with the prediction of the sector rule. Perhaps this deviation is due to a change in the conformation of the molecules by substitution at the 2-position and/or a change in the curvatures of the sectors. We are currently attempting to determine the absolute configurations of (-)2MPA and (-)2MP by chemical means in order to resolve this problem.

At present we are inclined to assign the Sconfiguration for the $l$-rotatory amino acids based on the above results and on the $\mathrm{CD}$ curves of their cyclic dimers [8] or polymer [3].

Acknowledgements-The authors are grateful for financial support from the National Institutes of Health under Grants 2R01-GM15256 and 2R01-CA12231-04, and the National Science Foundation under Grants DMR76-22246 and DMR 78-13400.

Dedication-The senior author (C. G. Overberger) dedicates this paper to Professor Oto Wichterle for his enormous contribution to macromolecular science, and in honour of his 70 th birthday.

\section{REFERENCES}

1. Present address: Macromolecular Research, Corporate Research and Development, International Minerals and Chemical Corporation, P.O. Box 207, Terre Haute, IN 47808, U.S.A

2. C. G. Overberger, K.-H. David and J. A. Moore, Macromolecules 5, 368 (1972).

3. C. G. Overberger and Y. S. Jon, J. Polym. Sci., Polym Chem. Ed. 15, 1413 (1977).

4. C. G. Overberger and M. J. Han, J. Polym. Sci., Polym. Chem. Ed. 13, 2251 (1975).

5. C. G. Overberger and K.-H. David, Macromolecules 5, 373 (1972) 
6. C. G. Overberger and M. J. Han, Pure appl. Chem. 39 , 33 (1974)

7. Mohamad D. Shalati and C. G. Overberger (in preparation).

8. Mohamad D. Shalati, C. G. Overberger and W. M. Butler (in preparation).

9. R. M. Zacharius, J. F. Thompson and F. C. Stewart, $J$. Am. chem. Soc. 74, 2949 (1952); ibid. 76, 2908 (1954).

10. V. W. Rodwell, Metabolic Pathways, (Edited by D. M. Greenberg), p. 191. Academic Press, New York (1970).

11. J. P. Greenstein and M. Winitz, Chemistry of Amino Acids. Wiley-Interscience, New York (1961).

12. E. Katchalski, A. Berger and J. Kurtz, Aspects of Protein Structures, (Edited by G. N. Ramachandran), p. 205. Academic Press, New York (1963).

13. J. Plostnieks, U.S. Patent 3,511,844 (1970); Ger. Offen. $1,913,534$ (1969)

14. A. Barco, S. Benetti and G. P. Pollini, Synthesis 316 (1973).

15. R. Borch, Tetrahedron Lett. 1, 61 (1968).

16. H. Meerwein, Org. Synth 46, 113 (1966).

17. M. V. Rubtsov, E. S. Nikitskyd and V. S. Usovskaya, J. gen. Chem., U.S.S.R. 26, 129 (1956).
18. G. Black, E. Depp and B. B. Corson, J. org. Chem. 14, 14 (1949).

19. F. Mende, Ber. Dtsch. chem. Ges. 29, 2887 (1896).

20. H. E. Carter, R. L. Frank and H. W. Johnston, Org. Synth. 3, 167 (1955)

21. E. Iizuka and J. T. Yang, Biochemistry 3, 1519 (1964).

22. J. Craig and S. K. Roy, Tetrahedron 39l (1965).

23. L. Fowden, P. M. Scopes and R. N. Thomas, J. chem. Soc. (C), 833 (1971)

24. J. C. Craig and W. E. Pereina, J. chem. Soc. (C), 1563 (1970).

25. A. V. Lakshminarayanan, V. Sgisekharan and G. N. Ramachandran, Conformation of Biopolymers, (Edited by G. N. Ramachandran), p. 78. Academic Press, London (1967).

26. C. Coulombeau and A. Rassat, Bull. Soc. chim. France 3752 (1966)

27. E. G. Höhn and O. E. Weigang, J. chem. Phys. 48, 1127 (1968); O. E. Weigang and E. G. Höhn, J. Am. chem. Soc. 88, 3673 (1976).

28. E. C. Jorgensen, Tetrahedron Lett. 863 (1971).

29. O. Lutz and B. Jirgensons, Ber. 63, 448 (1930); 64 (1931). 